Vol. 3, Issue I, pp. 1-11, 2021

Available online at: https://tljbm.org/jurnal/index.php/tljbm

\title{
The Mediation Effect of Lay Participation on the Relationship Between Transformational Leadership and Pastoral Effectiveness: Evidence from Saint Antonio Parish, Motael, Dili
}

\author{
Fr. Guilhermino da Silva, Salustiano dos Reis Piedade, Estanislau de Sousa Saldanha \\ Graduate School Master of Business Administration (MBA), Dili Institute of Technology (DIT), Dili, Timor-Leste \\ Email:pitankai70@gmail.com, piedade0709@gmail.com,pitankai70@gmail.com
}

\begin{abstract}
Pastoral effectiveness is an important factor in the success of pastoral activities in Catholic organizations, particularly at the parish level. Pastoral effectiveness can be influenced by transformational leadership and by lay participation. The aims of this research are (1) to examine and analyze the influence of transformational leadership and lay participation on pastoral effectiveness in Saint Antonio Parish, Motael, Dili, (2) examine the influence of transformational leadership on lay participation; and (3) to examine how lay participation mediates the relations between transformational leadership and pastoral effectiveness in this same parish. This research used questionnaires to collect data, with a total of 378 samples, and SMART-PLS 3.1 was used to analyze the data. The results of the research show that transformational leadership and lay participation indeed have a significant and positive influence on pastoral effectiveness. Transformational leadership also has significant impact on lay participation, while lay participation plays a significant role on the relationship between transformational leadership and pastoral effectiveness. This research could enrich the inferential studies on transformational leadership, lay participation and pastoral effectiveness in Catholic Church context which is still lacking. It also contributes to the improvement of pastoral effectiveness, especially within Saint Antonio Parish, Motael, Dili, and in the archdiocese of Dili in general by adopting transformational leadership and lay participation.
\end{abstract}

Keyword: Transformational leadership, lay participation, pastoral effectiveness, Catholic Parish, Timor-Leste.

\section{Introduction}

In the context of recent dynamic change, pastoral effectiveness is needed to ensure that Christians keep their faith in God and their commitment to humanistic values. To achieve this, parish priests play an important role in ensuring that Christian communities understand and implement Christian values in their lives (Cassimy, Jules, \& Satelmajer., 2009). Therefore, parish churches need good leadership to ensure pastoral activities are carried out effectively. Transformational leadership can be a good choice for parish priests because priests as transformational leaders will easily motivate, inspire, and encourage lay people to participate in carrying out church activities and achieving the parish' goals (Alapo, 2018). Carter (2009) in his study proved that pastoral activities can be undertaken well by priests who use transformational leadership due to priest with transformational leadership will motive, inspire and show the innovative and creative way to do new things together in order to finish effectively pastoral activities.

Parish priests need lay participation in pastoral activities, including spiritual, economic, moral, social and evangelism aspects. The Vatican II Council and Saint John Paul II outlined numerous pastoral activities in which laity can participate in ordinary family and social life, such as promoting the dignity of persons and life, defending legitimate freedom, protecting family life, and participating in charity and public life (Pham \& del Castillo, 2017).

Many previous studies have taken qualitative and descriptive approaches, a limited number used inferential approaches to measure the impact of transformational leadership and lay participation on pastoral effectiveness. Therefore, this study aims to: (1) examine and to analyse he impact of transformational leadership (TL) and lay participation (LP) on pastoral effectiveness (PE) in Saint Antonio Parish, Motael, Dili, and (2) examine and analyse the effect of lay participation on the relationship between transformational leadership and pastoral effectiveness in this same parish.

\section{Theoretical Framework, Research Model and Hypothesis 2.1. Transformational Leadership}

Transformational leadership is a process of engaging other people and establishing a relationship which will enhance the motivation and morality of both the leaders and their followers (Burns, 1978 as cited by Northouse, 2016). It can help followers better understand in order to be able to accept responsibility and the goals for the sake of the group. It responds to emotional needs, and also stimulates the intellect of followers (Bass, 1990). In turn, the followers have faith, admiration, loyalty and respect for the leaders. Thus, it motivates followers to work for the organization 
(Avolio and Bass, 2002). This style of leadership helps motivate followers to try achieve their potential (Yulk, 2010).

Bass no Riggio (2010) state that transformational leadership inspires followers to be committed to the vision and objectives of the organization, and challenges the leaders to be creative in dealing with problems (Allen, 2017). Northouse (2016:175) says that transformational leadership creates a culture in which followers are empowered and have the freedom to discuss and apply new methods. Transformational leadership likes to expand the knowledge of the workers and they in turn are eager to assist people, not just out of a concern for demands and security, but from a high level concern for the goals and development of the organization (Avolio et al., 1991; Chen \& Wu, 2020). Transformational leadership has four dimensions namely idealized influence, inspirational motivation, intellectual stimulation, and individualized consideration (Jensen et al., 2020).

Carter (2009) states that priests who opt for transformational leadership style most often engage in training and development for the progress of the church, providing good services for the group and its community. This is essential given that parishes have a great number of parishioners, but have insufficient priests to attend to them. Transformational leadership can prepare community leaders in order to attend to the needs of the parishioners, and allows parishioners too to actively participate as church members. Transformational leaders will be able to introduce new techniques and stimulate subordinates (parishioners) to do new things creatively and effectively (Liu \& Huang, 2020), which in turn leading to pastoral effectiveness.

Jordan (2019) states that leadership style has a direct and significant influence on effective coordination in the church. Dawkins (2011) in his research presents the impact of transformational leadership for senior priests and their followers both at individual and organizational level. Tucker and Russel (2004) say that transformational leadership increases both productivity and moral satisfaction. Numerous empirical studies revealed that transformational leadership has significant impact on commitment to change (Kim et al., 2021), business performance (Jensen et al., 2020), organization effectiveness (Van der Voet, 2014), and change (Islam et al., 2021). Therefore, transformational leadership may have strong impact on pastoral activities and effectiveness because good leaders who always motivate, inspire and become good role model to subordinates will stimulate them to work hard and timely delivered the tasks (Liu \& Huang, 2020).

\subsection{Lay participation}

The concept of lay participation is a general one used in in the universal Church, including mystic groups. Lay people are religious people who are not ordained (Broderick,
1976:335), a definition that goes as far back as Clement of Rome (Congar, Lay People in the Church: A Study for theology of the laity, 4).

Lay people play important roles in assisting the priests in carrying out church ministry. Pope Benedict XVI asserted lay people's important role in contributing concretely to the life of the church, as citizens of the Kingdom of Heaven (Lamb \& Lewering, 2008). Cassimy, Jules and Satelmajer (2009) confirm that both priests and laity are servants of the church in the world. Therefore, priests need to collaborate with lay people to support church mission (Cfr.AA.10).

Lay people organize things in the world according to God's plan. They are to be yeast in the world and to be holy. They too can make Christ known through their lives (Laurence Ryan, Vatican II: The Constitution on the Church, a theological and pastoral commentary, McNamara Kevin (Ed.) (Chicago: Franciscan Herald Press, 1968), 241). They preach Christ in their daily work through their own lives and the lives of their families, through their work and through other social work. Through Christian lay people, the light of the Gospel can illuminate their family life, their culture and tradition, their intelligence, their economy, their politics, their tasks, their struggles for human rights and for justice and peace, their care for the hungry and the sick, and their sharing of their possessions, etc. (Gakuna et al., 2018; Pham \& del Castillo, 2017). In many ways lay people are responsible for economic, political and social life. They cannot separate their life and the Gospel from their culture. Lay people must carry out their daily tasks faithfully as they respond to the spirit of the Gospel (Pham \& del Castillo, 2017).

The church document Lumen Gentium no CIC 1983 describes some indicators which can be used to know the participation of lay people in Christ's mission which they themselves have received through the baptism of Christ. In their baptism there are three functions of Christ that they should carry out: to be a prophet, to be a priest, and to be real in Christ. Based on these three tasks of Christ, they manifest their participation via engagement in different sections which have been established in the parish, including family, youth, and adolescence sections, taking part in the liturgy, lectionary readers, taking part in a categorical group, being a leader for the faith community in the parish within their suburb, and actively participating in the parish pastoral.

\subsection{Pastoral effectiveness}

Pastoral effectiveness is as the ability to manage and carry out pastoral activities as a shepherd in the church, according to the desired outcome. Efficiency means improving something to be better (Drucker, 1974). Pastoral effectiveness comes from a creative, innovative and effective leadership. This kind of leadership can be found in transformational leadership style. 
Vol. 3, Issue I, pp. 1-11, 2021

Available online at: https://tljbm.org/jurnal/index.php/tljbm

Pastoral effectiveness involves an ability to creatively do strategic planning to integrate all the church's resources with its pastoral activities, in line with the church' goals: to preach the Kingdom of God through evangelization, formation, catechism, liturgy and social charity, thus strengthening the church in the society (Cassimy, Jules, \& Satelmajer, 2009; McKenna \& Eckard, 2009; Nauss, 2014). Engaging willing and qualified followers in the church's pastoral work will help the pastoral work to be more effective and efficient (Allen, 2017; Pham \& del Castillo, 2017).

\subsection{Conceptual Framework}

The model used in this research is based on the idea that transformational leadership is important for pastoral activity, and that the participation of lay people is also important. It uses indicators for transformational leadership which were developed by Carter (2009), indicators for lay participation developed by Pham and Castilo (2017), and indicators for ministry effectiveness developed by McKenna and Eckard (2009. The research model is presented in Figure 1.

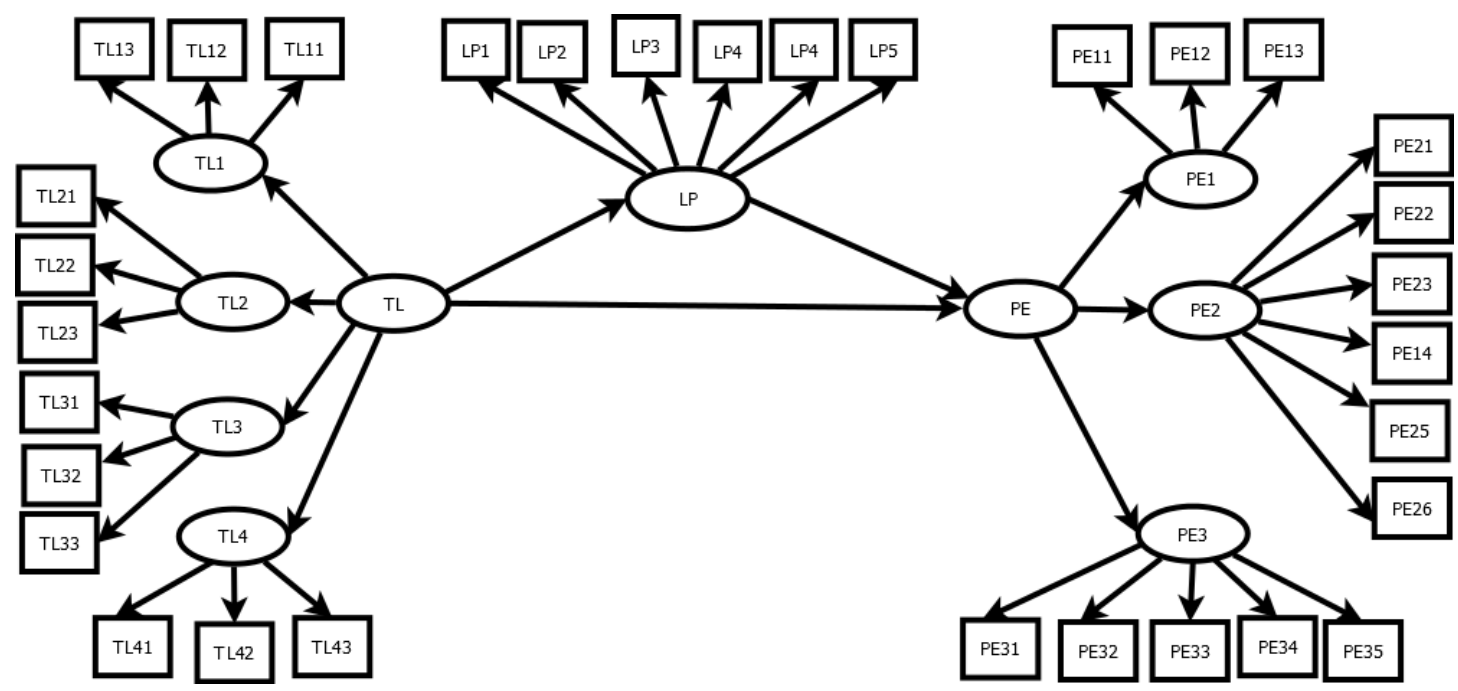

Figure I: The Research Model

\subsection{Hypothesis}

Generally, the priests are the transformational leadership (Alopo, 2018) of whom can motivate, inspire and as a model to lay persons to carry out pastoral activities effectively. Therefore, empirical studies revealed that transformational leadership has its significant impact for pastoral effectiveness in Catholic organizations (Allen, 2017). To this, in this research, the first hypothesis (H1) is formulated as follows:

$H_{1}$ : Transformational leadership significantly influences pastoral effectiveness in Saint Antonio Parish, Motael.

Priests with transformational leadership styles encourage lay people to work together to achieve the mission of the Church, thus having a big impact on its pastoral activity (Alapo, 2018). Pope Francis says that lay people are important people in the Catholic Church to carry out Catholic Church services (McElwee, 2015). Therefore, the second (H2) hypothesis for this research can be formulated as:
$\mathrm{H}_{2}$ : Transformational leadership significantly influences lay participation in Saint Antonio Parish, Motael, Dili.

The participation of lay people in many ministries within the Catholic Church has been discussed (Gakuna et al., 2018; Pham \& del Castillo, 2017). Their involvement can have a significant impact on transformational leadership and the pastoral effectiveness of the Parish (Allen, 2017). Therefore, the third hypothesis for this research (H3) is formulated as:

$H_{3}$ : The participation of lay people significantly influences pastoral effectiveness in Saint Antonio Parish, Motael, Dili.

Priests cannot carry out all the pastoral work in growing parishes. Even though, parish has transformational leadership, but since its resource limitations, parish activities are ineffective carry out (Gakuna et al., 2018; Nauss, 2014). In this regards, parish needs the participation of lay people to help the mission of the church (Cassimy, Jules, \& Satelmajer, 2009). Therefore, the fourth hypothesis of this research $(4 \mathrm{H})$ is formulated as: 


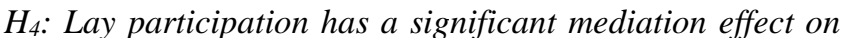
the relation between transformational leadership and pastoral effectiveness in Saint Antonio Parish, Motael, Dili.

\section{Research Method and Data Collection}

This research was done in Saint Antonio Parish, Motael, Dili. This is a large parish, with 34,451 church members, in 6,726 families (Saint Antonio Motael Parish Report, 2020), in 15 pastoral centers. Data was collected in the field from $1^{\text {st }}$ March until 20 ${ }^{\text {th }}$ March 2021. This research involved 378 families as respondents. To select respondents, a proportional sampling method based on the total number of families in the pastoral center, with the simple random method.

This was followed by data coding, entry, cleaning and analysis. This research used a questionnaire to collect data from the respondents. This questionnaire used a 5 point Likert 5 from which respondents chose, ranging from 1 (strongly disagree) to 5 (strongly agree). The indicators of transformational leadership were adopted from Carter (2009), the lay participation from Pham and Castilo (2017), and pastoral effectiveness from McKena and Eckard (2009). Before using this instrument, the researcher did a pretest with 30 respondents from within the Saint Antonio Parish in order to check that the respondents understood all the questions and answers. Their feedback helped to improve the questionnaire and avoid bias.

The data analysis was done by using SMART-PLS 3.1. This analysis was divided into three parts. The first part was to design a model in SMART-PLS on the relations between indicators and variables (outer model measurement), and between variables (inner model measurement) based on the previous empirical concepts and relevant theories (Hair et al., 2014). The second step was to examine the relation between indictors and variables (outer model measurement) in order to know the validity and reliability of the indicators or items that had been applied in the research. Validity test are of two types, namely convergent validity and discriminant validity. A convergent validity test uses parameter average variance extracted (AVE) and outer loading (OL). An item is normally considered valid when the value of AVE is greater than 0.5, and OL greater than 0.7. However, for explorative research, an OL value over 0.6 can be considered valid (Hair et al., 2014 no Hair et al., 2017). Discriminant validity tests use Fornell-Larcker Criterio (FL), Cross-load (Hair et al., 2014) and Heterotrait-Monotrait (HTMT). The item is valid when the value of HTMT is less than 0.90 (Henseler et al., 2015). The third step was to test the relation between variables (inner model measurement). This is to know the model prediction capacity $\left(\mathrm{Q}^{2}\right)$ and the correlation between variables $\left(\mathrm{R}^{2}\right)$. To test the hypothesis, this research used a $\mathrm{T}$ value and $P$ value in path coefficient (to test the significant influence between the variables). A variable is significantly influenced by another variable if the $\mathrm{T}$ value is greater than 1.96, and the $P$ value is less than 0.05 (Hair et al., 2014 and Hair et al., 2017).

\section{Results and Discussion 4.1. Respondent Characteristics}

The 378 respondents included $48.7 \%$ females, and $51.3 \%$ males. Most respondents $(82 \%)$ were aged from 21 50 years, $16.9 \%$ were over 50 , and $1.1 \%$ were aged 20 or less. The majority had completed secondary school (50.5\%), while Bachelor degree $39.4 \%$, diploma (4.5\%), completed primary school $(3.7 \%)$, and master degree $(1.9 \%)$. With regard to profession, $46.3 \%$ were public servants, $21.7 \%$ private sector, $13.2 \%$ owned business at home, 9.5\% students, $8.2 \%$ teachers, $5 \%$ catechists, $3 \%$ local leaders, and $3 \%$ religious.

\subsection{Validity and Reliability}

The analysis of validity is divided into two parts, namely convergent validity and discriminant validity. Convergent validity has two (2) ways of assessing it, namely outer loading (OL) and average variance extracted (AVE). Table I shows the outer loading (OL) values from the model of this research. OL values from all indicators are valid to indicate the greatest of 0.7. Thus, according OL principal it has convergent validity, this indicator is valid in order to assess this model because one indicator is valid when OL values is greater than minimum value 0.7 that acceptable (Hair et al., 2014 and Hair et al., 2017).

Table IV indicates AVE value indicators are greater than the minimum value of 0.5 , so all indicators in this model are valid according to the recommended value by Hair et al. (2014).

Discriminant validity was tested by using FornellLarcker Criterion (FL) (Table II), and Heterotrait-Monotrait (HTMT) (Table III). Thus, the latent variable is valid based on recommendation of Hair et al. (2014) to assessing inner model.

Table III shows that HTMT values from the indicators are all lower than 0.90 . Nevertheless, some indicators have HTMT values above 0.9. However, these indicators can still be used to reflect the variety of measurement. In addition, it does not also influence the content validity of the model (AVE value) (Hair et al., 2014). 
Vol. 3, Issue I, pp. 1-11, 2021

Table II. Fornell-Larcker Criterion for Discriminant Validity Test

\begin{tabular}{|c|c|c|c|c|c|c|c|c|c|c|}
\hline Construct & LP & $\mathbf{P E}$ & PE1 & PE2 & PE3 & TL & TL1 & TL2 & TL3 & TL4 \\
\hline LP & 0.75 & & & & & & & & & \\
\hline PE & 0.58 & & & & & & & & & \\
\hline PE1 & 0.52 & 0.83 & 0.85 & & & & & & & \\
\hline PE2 & 0.47 & 0.88 & 0.54 & 0.72 & & & & & & \\
\hline PE3 & 0.48 & 0.87 & 0.54 & 0.75 & 0.78 & & & & & \\
\hline TL & 0.65 & 0.76 & 0.73 & 0.62 & 0.57 & & & & & \\
\hline TL1 & 0.52 & 0.67 & 0.68 & 0.51 & 0.48 & 0.83 & 0.82 & & & \\
\hline TL2 & 0.54 & 0.63 & 0.61 & 0.52 & 0.45 & 0.84 & 0.62 & 0.81 & & \\
\hline TL3 & 0.59 & 0.64 & 0.58 & 0.54 & 0.48 & 0.87 & 0.59 & 0.67 & 0.85 & \\
\hline TL4 & 0.55 & 0.66 & 0.59 & 0.53 & 0.54 & 0.86 & 0.60 & 0.60 & 0.71 & 0.80 \\
\hline
\end{tabular}

Table III. Heterotrait-Monotrait (HTMT) for Discriminant Validity

\begin{tabular}{|c|c|c|c|c|c|c|c|c|}
\hline Construct & LP & PE1 & PE2 & PE3 & TL1 & TL2 & TL3 & TL4 \\
\hline PE1 & 0.632 & & & & & & & \\
\hline PE2 & 0.575 & 0.664 & & & & & & \\
\hline PE3 & 0.568 & 0.656 & 0.903 & & & & & \\
\hline TL1 & 0.642 & 0.859 & 0.653 & 0.591 & & & & \\
\hline TL2 & 0.674 & 0.784 & 0.672 & 0.566 & 0.810 & & & \\
\hline TL3 & 0.712 & 0.726 & 0.671 & 0.584 & 0.753 & 0.868 & & \\
\hline TL4 & 0.704 & 0.771 & 0.696 & 0.686 & 0.806 & 0.820 & 0.902 & \\
\hline
\end{tabular}

The reliability test uses two parameters, namely Cronbach's Alpha (CA) and Composite Reliability (CR). An indicator is valid when the value of $\mathrm{CA}$ and $\mathrm{CR}$ is higher than 0.7 (Hair et al., 2014 ho Hair et al., 2017). Table IV shows that the value of $\mathrm{CA}$ and $\mathrm{CR}$ is higher than 0.7 each respectively. Therefore, all indicators have good internal consistency.

Table IV. Composite Reliability, Cronbach's Alpha and Average Variance Extracted

\begin{tabular}{|c|c|c|c|}
\hline Construct & CA & CR & AVE \\
\hline TL & 0.75 & 0.86 & 0.67 \\
\hline LP & 0.84 & 0.88 & 0.56 \\
\hline PE & 0.82 & 0.88 & 0.61 \\
\hline
\end{tabular}

\subsection{Inner Model Analysis}

Table $\mathrm{V}$ shows the value of $\mathrm{R}$-Square in this model is 0.597 . This means that the relation between the variables in this model is moderately strong. That is, the variables within this model can predict $59.7 \%$ of the variation, but the rest cannot be predicted variables observed within this model.

Table V. The Value of R-Square $\left(\mathrm{R}^{2}\right)$

\begin{tabular}{|c|c|c|}
\hline Item & R Square & R Square Adjusted \\
\hline LP & 0.416 & 0.415 \\
\hline PE & 0.597 & 0.595 \\
\hline
\end{tabular}


Vol. 3, Issue I, pp. 1-11, 2021

Available online at: https://tljbm.org/jurnal/index.php/tljbm

\subsection{The Hypothesis Test}

The examination of the hypothesis is using path coefficient with parameter $\mathrm{t}$-statistic and probability ( $\mathrm{P}$ value). The relation between one variable and another is considered significant when the t-statistic value is higher than the minimum value or 1.96, and the probability value (P-value) is lower than 0.05 (Hair et al., 2014).

The result shows that the estimate value of path coefficient directly influences transformational leadership on pastoral effectiveness with a t-statistic value $10.513>1.96$, and $\mathrm{P}$ value $0.000<0$. 05. Thus, $\mathrm{H} 1$ is supported. In regard to the direct influences of the transformational leadership on the participation of lay people, the result of test in Table VI showed that the value of $t$-statistic $14.577>1.96$, and the probability value (P-value) 0,000 which is below than the threshold value of 0.05 . This result proves that hypothesis 2 $\left(\mathrm{H}_{2}\right)$ is accepted. Table VI also shows the estimation direct influences the lay participation on the pastoral effectiveness with the value of $t$-statistic $2.156>1.96$, and the $\mathrm{P}$ value
$0.032<0.05$. This result proves that hypothesis $3\left(\mathrm{H}_{3}\right)$ is supported.

The result of test shows that the estimation value of the path coefficient directly influences from the transformational leadership towards pastoral effectiveness with the value of tstatistic $10.513>1.96$, and P-value $0.000<0.05$. Therefore, $\mathrm{H} 3$ is accepted. The indirect test of lay participation on the relations between transformational leadership and pastoral effectiveness indicates that the value of $t$-statistic 2.069>1.96 and the P-value $0.039<0.05$. This outcome indeed supports hypothesis $4\left(\mathrm{H}_{4}\right)$ that the lay participation serves as a mediation variable between transformational leadership and pastoral effectiveness.

\subsection{Discussion}

The first objective of this research is to see the influence of transformational leadership on pastoral effectiveness. The outcomes show that transformational leadership does indeed

Table VI. T and P Value the Path Coefficient for Testing the Hypothesis

\begin{tabular}{|c|c|c|c|c|c|c|}
\hline Construct & $\begin{array}{c}\text { Original } \\
\text { Sample } \\
\text { (O) }\end{array}$ & $\begin{array}{c}\text { Sample Mean } \\
\text { (M) }\end{array}$ & $\begin{array}{l}\text { Standard } \\
\text { Deviation } \\
\text { (STDEV) }\end{array}$ & $\begin{array}{c}\text { T Statistics } \\
\text { (|O/STDEV|) }\end{array}$ & P Values & Note \\
\hline TL $>$ PE & 0.664 & 0.666 & 0.063 & 10.513 & 0.000 & Significant \\
\hline TL $->$ LP & 0.645 & 0.647 & 0.044 & 14.577 & 0.000 & Significant \\
\hline LP -> PE & 0.155 & 0.154 & 0.072 & 2.156 & 0.032 & Significant \\
\hline $\mathrm{TL} \rightarrow \mathrm{LP} \rightarrow \mathrm{PE}$ & 0.100 & 0.100 & 0.048 & 2.069 & 0.039 & Significant \\
\hline
\end{tabular}

have a positive and significant influence on pastoral effectiveness. This confirms previous research which indicated that transformational leadership can enhance the effectiveness of the work of staff (Yammarino \& Dubinsky, 1994) because it contributes to strengthening their consciousness, interest and trust, and to motivate staff to improve their work, so that they can give their best to achieve the objectives of the organization. The outcomes of this research are also in line with the results of research by Han, Oh and Kang (2020), which shows that priests as transformational leaders are able to help workers understand and discover the value of their work and lead them to reach high work performance which in turn lead to enhance organization performance (Van der Voet, 2014; Jensen et al., 2020; Kim et al., 2021); Islam et al., 2021). Priests with transformational leadership style in the church have an important role in determining the effectiveness of the services of the church (Allen, 2017). For this reason, a lot of priests prefer to adopt transformational leadership. A priest that uses transformational leadership will satisfy his people and himself through his work in the parish because he has creativity and the capacity to motivate and inspire. He is not only a visionary but also able to lead and to act as a role model (Cassimy, Jules, \& Satelmajer, 2009), and to stimulate people to work as a team by dealing with interpersonal differences in order to achieve the common goal (Nauss, 2014; Liu \& Huang, 2020).

The second objective of this research is to examine the influence of transformational leadership on lay participation. The outcomes of the research indicate that transformational leadership positively and significantly influences lay participation in Saint Antonio Parish, Motael, Dili. This indicates that the parish priest has implemented the values of transformational leadership, namely idealized influence, inspirational motivation, intellectual stimulation, and individual consideration. Cassimy, Jules and Satelmajer (2009) say that a priest cannot do everything, yet he can guarantee that all work is done properly. A priest is responsible for the implementation of the church program with the help of the laity. The parish priest leads lay participation in church ministry and other related work in the local church (Dodson, 2018). In order to do fruitful work, a parish needs the involvement of laity in its ministry (Cassimy, Jules, \& Satelmajer, 2009). This study confirms that transformational leadership will motivate, inspire and lead subordinates to engage more in works in order to creatively take organization to continuous change and ultimately achieve high organization performance (Liu \& Huang, 2020). 
Vol. 3, Issue I, pp. 1-11, 2021

Available online at: https://tljbm.org/jurnal/index.php/tljbm

The third objective of this research is to examine to influence the lay participation on pastoral effectiveness. The outcomes indicate that lay participation has positively and significantly influenced pastoral effectiveness in Saint Antonio Parish, Motael, Dili. This means that the more the laity takes part in Church ministry, the more the Church will achieve pastoral effectiveness. Through concrete lay participation in pastoral work, and with the support of the parish priest in administering the sacraments of baptism, first communion, and matrimony, doctrinal teaching, and preaching the word of God, managing the administration in the secretariat of the church, developing a plan, and doing youth ministry, indeed have a positive impact on pastoral effectiveness, objective outcomes, and ministry outcome. This confirms that high people's participation in organization activities will increase organization effectiveness (Van der Voet, 2014) and performance. Transformational leaders provide continuous supportive behaviors to lay persons to understand pastoral activities and the goals of church organizations, stimulating them to solve pastoral problems from different perspectives, and encouraging them and provide resources to subordinate to perform better than before (Chen \& Wu, 2020).

The fourth objective of this research is to examine mediation effect of lay participation in the relation between transformational leadership and pastoral effectiveness. The outcomes of the research indicate that this mediation has a positive and significant effect. That is, lay participation significantly contributes to the relations between transformational leadership and pastoral effectiveness. It is thus clear that lay participation is important in the development of the church, with the support of the parish priest to implement pastoral activities in St Antonio Parish, Motael. Gidudu (2002) affirms that lay participation has an important role in sharing the good news in the parish and in their community. McGarry (2002) quotes the Synod of Bishops in Africa as affirming that lay participation is an important element in the process of the evangelization. Because it is a key element in evangelization it can enhance pastoral performance (Gakuna, 2019).

\section{Conclusion and Implication}

The conclusions supported by this research are: (1) Transformational leadership positively and significantly influences pastoral effectiveness. (2) Transformational leadership positively and significantly influences lay participation. (3) The participation of lay people positively and significantly influences pastoral effectiveness. (4) Lay participation serves as mediation between transformational leadership and pastoral effectiveness. This means that the better the leadership and the more the lay participation, the higher the pastoral effectiveness.

The implication of this research is that pastoral effectiveness can be achieved if parish priest can adopt transformational leadership to motivate, inspire and become model for lay persons to participate church religious and social missions. Transformational leadership and lay participation in parish religious and social activities will help parish priest to reach its goals effectively.

\section{Limitations and Future Research}

This research was conducted in order to examine pastoral effectiveness as influenced by transformational leadership and lay participation. Since this was only preliminary research, there are a number of limitations: (1) The research is restricted to Saint Antonio Parish, Motael, Dili, with 378 respondents. Therefore, the results cannot be generalized to all parishes in Timor-Leste. Future research could be done in other parishes so that a comparison can be done. (2) This research used a questionnaire as the only instrument for data collection. In future, other instruments such as in-depth interviews, focus group discussions and observation can be used as well to get more comprehensive data.

\section{References:}

Alapo, R. (2018). Ministerial Leadership: The Servant Leader as a Transformational Leader. Philosophy Study, 8(1), 12-16.

Allen, D. H. (2017). Pastoral Transformational Leadership and Church Human Service Provision. In ProQuest Dissertations and Theses. Walden University.

Avolio, B. J., Waldman, D. A., \& Yammarino, F. J. (1991). The Four I' $\mathrm{s}$ of Leadership. Journal of European Industrial Training, $15(4), 9-16$.

Carter, J. C. (2009). Transformational leadership and pastoral leader effectiveness. Pastoral Psychology, 58(3), 261-271.

Cassimy, S. D., Jules, A. J., \& Satelmajer. (2009). A Guide to Effective Pastoral Ministry. Pacific Press.

Cassimy, S. D., Jules, A. J., \& Satelmajer, N. (2009). A Guide to Effective Pastoral Ministry. Pacific Press ${ }^{\circledR}$ Publishing Association. Chen, T. J., \& Wu, C. M. (2020). Can newcomers perform better at hotels? Examining the roles of transformational leadership, supervisor-triggered positive affect, and perceived supervisor support. Tourism Management Perspectives, 33(529).

Dawkins, H. A. (2011). Transformational Leadership: A Contribution to the Effectiveness of Congregationally Formed Faith-Based Community Development Corporations. St. John Fisher College.

Dodson, C. (2018). Pastoral Leadership Behaviors and the Involvement of Local Church Laity. In Doctoral Dissertations and Projects. Liberty University, School of Business.

Gakuna, P. K. (2019). Factors influencing the Catholic Laity in the Evangelization. 
Vol. 3, Issue I, pp. 1-11, 2021

Available online at: https://tljbm.org/jurnal/index.php/tljbm

Gakuna, P. K., Juma, F., \& Ayiemba, J. (2018). Examining the extent to which the laity participates in evangelization in Njoro. East African Scholars Journal of Education, Humanities and Literature, 1(2), 55-61.

Hair, J. F., Sarstedt, M., Hopkins, L., \& G. Kuppelwieser, V. (2014). Partial least squares structural equation modeling (PLSSEM). European Business Review, 26(2), 106-121.

Han, S. H., Oh, E. G., \& Kang, S. "Pil." (2020). The link between transformational leadership and work-related performance: moderated-mediating roles of meaningfulness and job characteristics. Leadership and Organization Development Journal, 41(4), 519-533.

Islam, M. N., Furuoka, F., \& Idris, A. (2021). Mapping the relationship between transformational leadership, trust in leadership and employee championing behavior during organizational change. In Asia Pacific Management Review (Vol. 26, Issue 2, pp. 95-102).

Jensen, M., Chaudhry, S., \& Chaudhry, S. (2020). A mixedmethods study of CEO transformational leadership and firm performance. European Management Journal.

Jordan, H. (2019). Leadership Factors That Influence Church Growth for Western North Carolina Churches of God. Liberty University School of Divinity.

Kim, H., Im, J., \& Shin, Y. H. (2021). The impact of transformational leadership and commitment to change on restaurant employees' quality of work life during a crisis. Journal of Hospitality and Tourism Management, 48(January), 322-330.
Lamb, M. L., \& Lewering, M. (Eds.). (2008). Vatican II Renewal within Tradition. Oxford University Press, Inc.

Liu, C. H. S., \& Huang, Y. C. (2020). The influence of transformational leadership on subordinate creative behaviour development process. Tourism Management Perspectives, 36(September).

McKenna, R. B., \& Eckard, K. (2009). Evaluating pastoral effectiveness: To measure or not to measure. Pastoral Psychology, 58(3), 303-313.

Nauss, A. (2014). Ministerial Effectiveness in Ten Functions. Review of Religious Research, 36(1), 58-69.

Northouse, P. G. (2016). Leadership-Theory and Practice. SAGE Publications, Inc.

Pham, T. T. B., \& del Castillo, F. (2017). An Analysis of the Lay Participation to Vocation Promotion in Vietnam. 5(3), 93-101.

Van der Voet, J. (2014). The effectiveness and specificity of change management in a public organization: Transformational leadership and a bureaucratic organizational structure. European Management Journal, 32(3), 373-382.

Yammarino, F. J., \& Dubinsky, A. J. (1994). Transformational Leadership Theory: Using Levels of Analysis To Determine Boundary Conditions. Personnel Psychology, 47(4), 787-811.

Yulk, G. (2010). Leadership in organizations (7 Edtion). Prentice Hall.

\section{Appendix A: Outer Loadings}

Table I. Outer Loading Values for Convergent Validity

\begin{tabular}{|c|c|c|c|c|c|c|c|c|}
\hline Construct & $\mathbf{L P}$ & PE1 & PE2 & PE3 & TL1 & TL2 & TL3 & TL4 \\
\hline LP11 & 7 & & & & & & & \\
\hline LP12 & 00.08 & & & & & & & \\
\hline LP13 & 00.08 & & & & & & & \\
\hline LP14 & 00.07 & & & & & & & \\
\hline LP15 & 00.08 & & & & & & & \\
\hline LP16 & 00.07 & & & & & & & \\
\hline PE11 & & 00.08 & & & & & & \\
\hline PE12 & & 00.09 & & & & & & \\
\hline PE13 & & 00.08 & & & & & & \\
\hline PE21 & & & 00.07 & & & & & \\
\hline PE22 & & & 00.08 & & & & & \\
\hline PE23 & & & 00.08 & & & & & \\
\hline PE24 & & & 00.08 & & & & & \\
\hline
\end{tabular}


Vol. 3, Issue I, pp. 1-11, 2021

Available online at: https://tljbm.org/jurnal/index.php/tljbm

\begin{tabular}{|c|c|c|c|c|c|c|}
\hline PE25 & 00.06 & & & & & \\
\hline PE26 & 00.07 & & & & & \\
\hline PE31 & & 00.07 & & & & \\
\hline PE32 & & 00.08 & & & & \\
\hline PE33 & & 00.08 & & & & \\
\hline PE34 & & 00.08 & & & & \\
\hline PE35 & & 00.08 & & & & \\
\hline TL11 & & & 00.08 & & & \\
\hline TL12 & & & 00.08 & & & \\
\hline TL13 & & & 00.08 & & & \\
\hline TL21 & & & & 00.08 & & \\
\hline TL22 & & & & 00.08 & & \\
\hline TL23 & & & & 00.08 & & \\
\hline TL31 & & & & & 00.08 & \\
\hline TL32 & & & & & 00.09 & \\
\hline TL33 & & & & & 00.09 & \\
\hline TL41 & & & & & & 00.07 \\
\hline TL42 & & & & & & 00.08 \\
\hline TL43 & & & & & & 00.08 \\
\hline
\end{tabular}

\section{Appendix B: Outer Loadings}

\section{Transformational Leadership (TL)}

Please choose the correct answer according to you.

Strongly disagree (SD), 2. Disagree (D), 3 Neutral (N), 4. Agree (A), 5. Strongly Agree (SA).

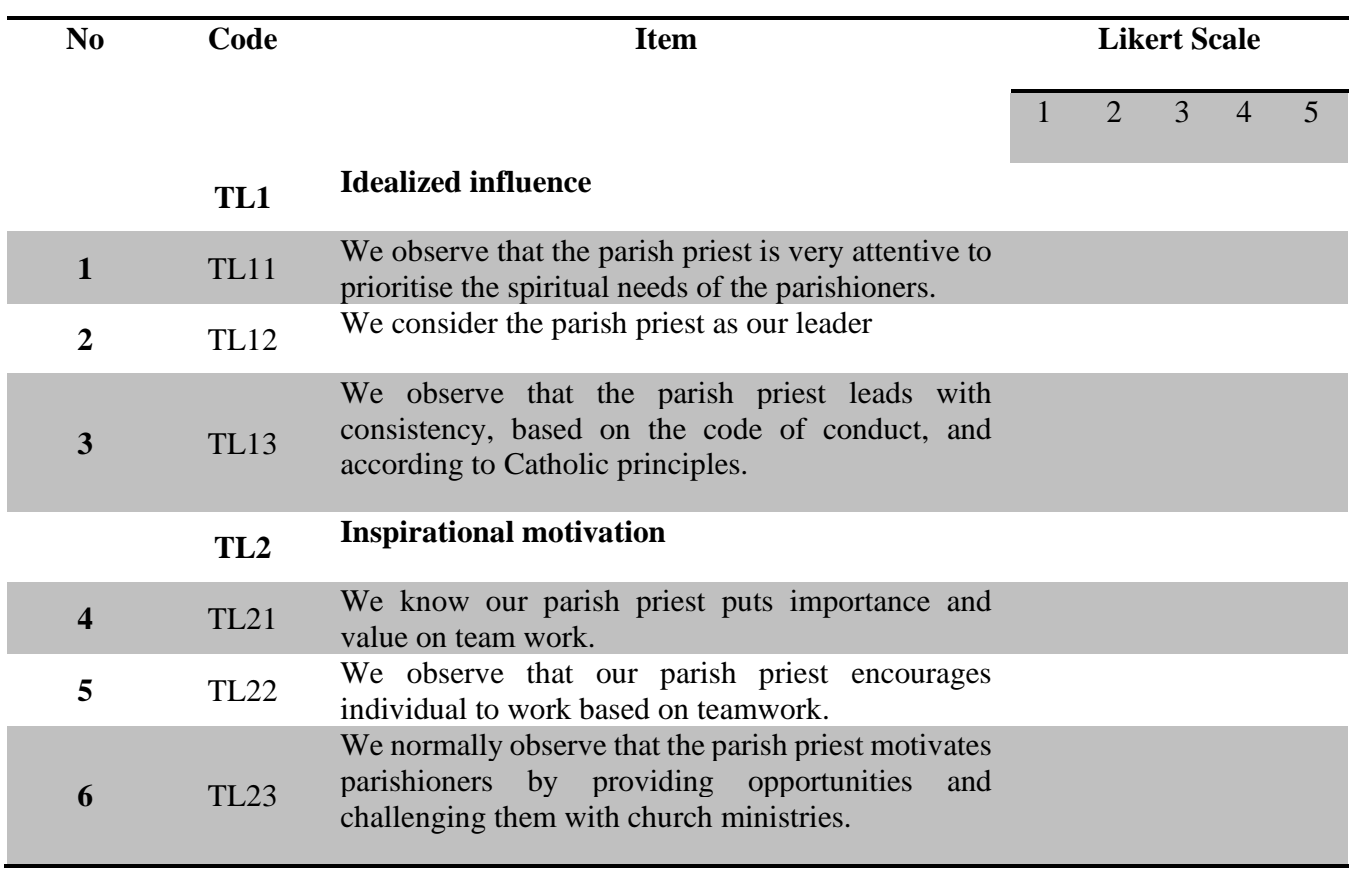




\begin{tabular}{lll}
\hline $\mathbf{7}$ & TL3 & $\begin{array}{l}\text { Intellectual stimulation } \\
\text { We observe that the parish priest stimulates } \\
\text { creativity and innovation to deal with challenges in } \\
\text { the parish. } \\
\text { TL31 }\end{array}$ \\
$\mathbf{9}$ & TL32 & $\begin{array}{l}\text { We observe the parish priest applies new methods to } \\
\text { solve challenges in the parish. } \\
\text { We observe the parish priest suggests new ways of } \\
\text { dealing with challenges in the parish. } \\
\text { Individualized consideration }\end{array}$ \\
$\mathbf{1 0}$ & TL41 & $\begin{array}{l}\text { We observe the parish priest recognizes the } \\
\text { uniqueness of each member in their needs and their } \\
\text { desires. } \\
\text { We observe the parish priest assists the parishioners } \\
\text { to develop their talents. } \\
\text { We observe the parish priest pays attention to the } \\
\text { needs of of each parishioner to improve themselves. }\end{array}$ \\
\hline
\end{tabular}

\section{Lay Participation (LP)}

Please choose the correct answer according to you.

Strongly disagree (SD), 2. Disagree (D), 3 Neutral (N), 4. Agree (A), 5. Strongly Agree (SA).

\begin{tabular}{|c|c|c|c|c|c|}
\hline \multirow[b]{2}{*}{ No } & \multirow[b]{2}{*}{ Code } & \multirow[b]{2}{*}{ Item } & \multicolumn{3}{|c|}{ Likert Scale } \\
\hline & & & 1 & $\begin{array}{lll}2 & 3 & 4\end{array}$ & 5 \\
\hline 1 & LP11 & $\begin{array}{l}\text { Lay participation supports the parish priest to take } \\
\text { care of the youth. }\end{array}$ & & & \\
\hline 2 & LP12 & $\begin{array}{l}\text { Lay participations assist the parish priest to do the } \\
\text { pastoral planning of the parish. }\end{array}$ & & & \\
\hline 3 & LP13 & $\begin{array}{l}\text { Lay participation assists the parish priest to manage } \\
\text { the secretariat of the parish. }\end{array}$ & & & \\
\hline 4 & LP14 & $\begin{array}{l}\text { Lay participation assists the parish priest to visit the } \\
\text { sick and the needy and to support them in the parish }\end{array}$ & & & \\
\hline 5 & LP15 & $\begin{array}{l}\text { Lay participation assists the parish priest to teach } \\
\text { church doctrine to the children and the youth and to } \\
\text { preach the good news in the parish. }\end{array}$ & & & \\
\hline 6 & LP16 & $\begin{array}{l}\text { Lay participation assists the parish priest to } \\
\text { administer baptism, first communion, and the } \\
\text { sacrament of appointment and matrimony. }\end{array}$ & & & \\
\hline
\end{tabular}

\section{Pastoral Effectiveness (PE)}

Please choose the correct answer according to you.

Strongly disagree (SD), 2. Disagree (D), 3 Neutral (N), 4. Agree (A), 5. Strongly Agree (SA).

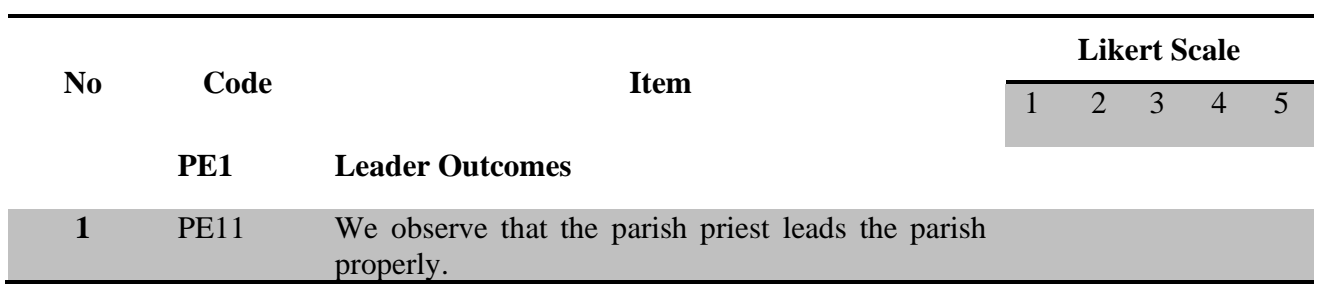




\begin{tabular}{|c|c|c|}
\hline 2 & PE12 & $\begin{array}{l}\text { We observe that the parish priest has clear vision, } \\
\text { mission, and objectives in order to develop the } \\
\text { parish. }\end{array}$ \\
\hline \multirow[t]{2}{*}{3} & PE13 & $\begin{array}{l}\text { We observe that the parish priest communicates his } \\
\text { vision and mission well to the parishioners. }\end{array}$ \\
\hline & PE2 & Objective Outcomes \\
\hline 4 & PE21 & $\begin{array}{l}\text { We observe that the number of parishioners who } \\
\text { participate in meshes has increased in the last three } \\
\text { years. }\end{array}$ \\
\hline 5 & PE22 & $\begin{array}{l}\text { We observe that the number of parishioners who } \\
\text { have registered their children for baptism has } \\
\text { increased in the last three years. }\end{array}$ \\
\hline 6 & PE23 & $\begin{array}{l}\text { We observe that the numbers of parishioners who } \\
\text { registered their children for receiving the sacrament } \\
\text { of matrimony has increased in the last three years. }\end{array}$ \\
\hline 7 & PE24 & $\begin{array}{l}\text { We observe that alms have increased in the parish in } \\
\text { the last three years. }\end{array}$ \\
\hline 8 & PE25 & $\begin{array}{l}\text { We observe that the number of people who are } \\
\text { actively using the assets of the parish has increased } \\
\text { in the last three years. }\end{array}$ \\
\hline \multirow[t]{2}{*}{9} & PE26 & $\begin{array}{l}\text { We observe that the numbers of volunteers who } \\
\text { support the parishioners has increased in the last } \\
\text { three years. }\end{array}$ \\
\hline & PE3 & Ministry Outcomes \\
\hline 10 & PE31 & $\begin{array}{l}\text { The services and evangelization by the parish priest } \\
\text { strengthen our spiritual faith. }\end{array}$ \\
\hline 11 & PE32 & $\begin{array}{l}\text { We are happy with the parish priest and respect of } \\
\text { him. }\end{array}$ \\
\hline 12 & PE33 & $\begin{array}{l}\text { We open to work with parish priests in the last three } \\
\text { years. }\end{array}$ \\
\hline 13 & PE34 & $\begin{array}{l}\text { We observe that the alms given by the parishioners } \\
\text { has increased in the last three years. }\end{array}$ \\
\hline 14 & PE35 & $\begin{array}{l}\text { We observe that the numbers of parishioners } \\
\text { participating in mass has increased in the last three } \\
\text { years. }\end{array}$ \\
\hline 15 & PE36 & $\begin{array}{l}\text { We observe that young people are enthusiastic to } \\
\text { participate in the mass in the last three years. }\end{array}$ \\
\hline
\end{tabular}

